\title{
Effect of Tomato Rootstock on Hybrid and Heirloom Tomato Performance in a Midwest High Tunnel Production System
}

\author{
Kristine M. Lang ${ }^{1}$ \\ Department of Horticulture, Iowa State University, 260 Horticulture Hall, \\ Ames, IA 50011
}

\author{
Ajay Nair ${ }^{2,3}$ \\ Department of Horticulture, Iowa State University, 145 Horticulture Hall, \\ Ames, IA 50011
}

Additional index words. grafting, lycopene, scion, Solanum lycopersicum, vegetable

\begin{abstract}
High tunnels allow vegetable growers to extend the growing season, increase crop production, and improve produce quality. Tomatoes (Solanum lycopersicum $\mathrm{L}$.) are the most widely grown crops in high tunnels; however, tomato production in high tunnels can be challenging. Continuous cropping in high tunnels can increase soil-borne disease pressure and can lead to soil salinity or nutrient depletion issues. Based on preliminary research, we hypothesized that use of the rootstock 'RST-04-106-T' would increase yield and quality of heirloom and hybrid tomato scions compared with nongrafted plants. To test this hypothesis, our research objectives were to assess marketable yields, fruit quality and nutritional value, and plant growth of grafted and nongrafted hybrid and heirloom tomatoes in a high tunnel production system. Grafted and nongrafted 'Cherokee Purple' (heirloom) and 'Mountain Fresh Plus' (hybrid) tomatoes were grown in the same high tunnel for two seasons (7 May-20 Oct. 2015 and 29 April-7 Oct. 2016) at the Horticulture Research Station in Ames, IA. Grafted plants produced significantly more marketable fruit, although marketable and total fruit weight did not increase significantly. Individual fruit size was unaffected by grafting. Across cultivars, mean soluble solids content (SSC) in fruit was $0.3{ }^{\circ} \mathrm{Brix}$ lower in grafted plants as compared with the nongrafted control. Grafting did not affect lycopene content of fruit. Grafting increased stem diameter by an average of $0.8 \mathrm{~mm}$, but overall plant biomass was unaffected. The effect of grafting on leaf chlorophyll concentration (SPAD readings) was mixed. In addition, grafting increased leaf chlorophyll concentration in 'Cherokee Purple' but decreased it in 'Mountain Fresh Plus' plants. Grafting is a valuable tool in tomato production, but the impact of 'RST-04-106-T' rootstock use appears to be specific to certain soil types with high incidence of bacterial wilt.
\end{abstract}

The tomato (Solanum lycopersicum L.) is the fifth most important crop in Iowa vegetable production, and although most tomatoes in Iowa are produced in open fields, the number of farms producing tomatoes under protection rose from 90 to 184 farms between 2007 and 2012 (U.S. Department of Agriculture [USDA], National Agricultural Statistics Service, 2014). A high tunnel is a solarheated, passively ventilated, plastic-covered structure that lengthens the growing season for high-value specialty crops (Jett, 2017). In some parts of the world, high tunnels shield

Received for publication 10 Jan. 2019. Accepted for publication $22 \mathrm{Feb} .2019$.

We thank the Iowa Department of Agriculture and Land Stewardship Specialty Crop Block Grant Program for the financial support to conduct this research.

${ }^{1} \mathrm{PhD}$ candidate.

${ }^{2}$ Associate Professor.

${ }^{3}$ Corresponding author. E-mail: nairajay@iastate. edu.

840
Grafting scions to vigorous rootstocks is one way to overcome many of the aforementioned issues related to high tunnel production (Kubota et al., 2008; Lee et al., 2010). Vegetable grafting first emerged in Japan and Korea to overcome soil-borne diseases (Lee et al., 2010), and the practice has gained interest on a larger scale in the United States within the past 10 years (Kubota et al., 2008). Researchers have demonstrated the benefits of grafting, but within the United States and Canada, breeding and selection of new tomato rootstocks is limited as compared with other countries (King et al., 2010).

Perhaps the most impactful result of grafting tomatoes is greater resistance to soil-borne pests, such as root-knot nematode (Barrett et al., 2012a), verticillium wilt (Buller et al., 2013; Liu et al., 2009), fusarium crown and root rot (Vitale et al., 2014), and bacterial wilt (McAvoy et al., 2012). Specific rootstocks need to be developed, researched, and used for these and other biotic pressures (Guan et al., 2012; Louws et al., 2010). Grafting also has been used to overcome abiotic factors, including organic pollutants (Schwarz et al., 2010) and suboptimal temperatures (Ntatsi et al., 2014; Schwarz et al., 2010). Scion-rootstock interactions can influence plant response to both drought and flooding (Bhatt et al., 2015; Nilsen et al., 2014; Sánchez-Rodríguez et al., 2012; Schwarz et al., 2010).

Two areas of debate regarding grafting are the influence of grafted rootstocks on soil nutrient interactions and the rootstock effects on scion fruit quality. Grafting may alter plant nutrient interactions, usually by decreasing the external inputs required for the system (Djidonou et al., 2013, 2015; Leonardi and Giuffrida, 2006; Schwarz et al., 2013). However, whether grafting can overcome soil salinity and fertilizer build-up issues is unclear (Asins et al., 2015; Borgognone et al., 2013; Fan et al., 2011). Some have reported a benefit of vegetable grafting is the potential to increase fruit quality (Flores et al., 2010), whereas others indicate the results are inconclusive (Barrett et al., 2012b; Nicoletto et al., 2013; Rouphael et al., 2010).

Given the high monetary inputs required for vegetable grafting (labor, tools, seed, and space), one must consider the economic return of a crop produced with grafted plants. Several studies have shown that the cost of grafting can be offset by combating pest pressure (Barrett et al., 2012a), increasing overall yield at a certain threshold (Rysin and Louws, 2015), and improving fruit quality to allow for premium product pricing (Rysin et al., 2015). Furthermore, the use of grafted plants has potential economic benefits, but each situational outcome is dependent on a variety of factors (Barrett et al., 2012a; Lewis et al., 2014; Rysin and Louws, 2015; Rysin et al., 2015).

Although there have been several studies reported that demonstrate the impacts of vegetable grafting, the need for localized research is still high (Kubota et al., 2008). 
During the fourth National Vegetable Grafting Symposium in Grand Rapids, MI, a call to action urged researchers to continue exploring scion-rootstock interactions in response to regional production issues (M. Kleinhenz and C. Rivard, personal communication, 7 Dec. 2015). Growers within Iowa have expressed interest in vegetable grafting and exploring benefits it may provide. Pairing localized interest with a national call for research encouraged us to explore grafting as a mechanism to improve high tunnel production of this high-value crop within the Midwest. High tunnel production issues, such as soil-borne diseases, are less prevalent in Iowa as reported by farmers, likely due to the short history of high tunnel tomato production in the state, as compared with surrounding states (Enderton et al., 2017; J. Hannan, personal communication, 5 Nov. 2018); however, high tunnel tomato production is increasing, and improvements in tomato yield or fruit quality because of grafting could have an important economic impact for local growers (Enderton et al., 2017).

The tomato rootstock 'RST-04-106-T' was selected for this study based on a preliminary trial conducted in Ames and Atlantic, IA, in 2014 as 'Mountain Fresh Plus' grafted to 'RST-04-106-T' showed significantly higher yield than the nongrafted treatment (A. Nair, unpublished data). We hypothesized that use of the rootstock 'RST-04-106-T' would increase yield and quality of heirloom and hybrid tomatoes compared with nongrafted plants. The objective of this research was to test the effects of grafting with a hybrid cultivar and an heirloom tomato cultivar and compare these with two nongrafted controls. We examined differences among treatments for total and marketable fruit yields, fruit quality and nutritional value, and plant growth and vigor.

\section{Materials and Methods}

Site description. Trials were conducted in 2015 and 2016 in a $9.1 \times 3.7 \times 29.3-\mathrm{m}$ ClearSpan high tunnel covered with 6-mmthick polyethylene film (Farmtek, Dyersville, IA) at the Iowa State University Horticulture Research Station in Ames, IA. The high tunnel was equipped with motorized roll-up sides set to open when the temperature at $1 \mathrm{~m}$ above the soil reached $26.7^{\circ} \mathrm{C}$ as read by a sensor attached to a thermostat control panel (Posi-Clasp Roll-Lock, Model \#VCU1; Advancing Alternatives, Lancaster, PA). The same high tunnel was used for both seasons and had previously been used to grow sweet corn (Zea mays var. saccharata var. rugose) (2015) and tomatoes and cover crop (2014). The soil within the high tunnel was a Clarion loam with $2.4 \%$ organic matter as indicated by a soil test collected on 7 May 2015 and submitted to a local soil-testing facility (Solum, Ames, IA). Irrigation water was pumped from a pond located at the research station. No symptoms of abiotic or biotic diseases were observed on plant material in either season with the exception of leaf mold (Passalora fulva) in
2015 that was first observed on 21 Aug. in 'Mountain Fresh Plus' and observed on 18 Sept. in 'Cherokee Purple'. The presence of leaf mold was ubiquitous across grafted and nongrafted plants.

Experimental design. The experimental design was a randomized complete block with four replications each running the length of the high tunnel. There were $1.5 \mathrm{~m}$ between rows and $1.8 \mathrm{~m}$ between plots within replications. Each treatment plot was $4.6 \mathrm{~m}$ in length with 10 plants spaced at $0.46 \mathrm{~m}$ within rows. A guard row of sweet alyssum ( $\mathrm{Lobu}$ laria maritima) was planted on both sides of the high tunnel to attract hoverflies (Syrphidae) and serve as a biological control measure (Brennan, 2013). Treatments included two cultivars (Cherokee Purple or Mountain Fresh Plus) and combinations of the cultivars as grafted and nongrafted plants. The rootstock used was 'RST-04-106-T' (DP Seeds, Yuma, AZ), a hybrid rootstock bred for resistance to Ralstonia solanacearum, Fusarium, and Tomato mosaic virus.

Transplant production. Seeds of 'RST04-106-T', 'Mountain Fresh Plus' (Johnny's Selected Seeds, Winslow, ME), and 'Cherokee Purple' (Johnny’s Selected Seeds), were sown in 98-cell propagation trays in 2015, and in 288-cell propagation trays that were later transplanted to 72-cell trays (scion) and 606-cell packs (rootstock) in 2016. Trays were filled with a soilless potting mix (Metro Mix 360; Sun Gro Horticulture, Agawam, MA). Tomatoes were seeded on 19 Mar. 2015 and 11 Mar. 2016 and grown in a greenhouse maintained at 20 to $22{ }^{\circ} \mathrm{C}$ from 0600 to 2200 $\mathrm{HR}$ and 17 to $19{ }^{\circ} \mathrm{C}$ from 2200 to $0600 \mathrm{HR}$. Supplemental irradiance was provided during 0600 to $2200_{\mathrm{HR}}$ with $1000-\mathrm{W}$, high-pressure sodium lamps. Three weeks after seeding, seedlings were grafted using the splice grafting method on 8 Apr. 2015 and 1 Apr. 2016 (Lee et al., 2010). The rootstock stem was cut at a 45-degree angle below the cotyledon (seed leaf). The scion stem was cut at the same angle above the cotyledon. No true leaves were trimmed or removed from any of the grafted plants. The two stems were joined together and held in place with a 2-mm silicon grafting clip (Johnny's Selected Seeds). The transplants were then placed in a high humidity ( $80 \%$ to $95 \%)$ healing chamber constructed of polyvinyl chloride pipe and clear polyethylene plastic. The temperature within the healing chamber averaged $24{ }^{\circ} \mathrm{C}$. Irradiance was blocked from the chamber with black plastic for $2 \mathrm{~d}$ after grafting. After 2 days, the black plastic was removed from the healing chamber while plants remained inside. One week after grafting, all plants were removed from the healing chamber and acclimated to ambient greenhouse conditions. Plants were watered as needed and fertilized seven times $(10,13$, $15,17,41,42$, and $44 \mathrm{~d}$ after seeding) each season using a water-soluble fertilizer (15-515 Peters Excel Multi-Purpose and Cal-Mag; Everris International, Geldermalsen, The Netherlands) with $\mathrm{N}$ at $150 \mathrm{mg} \cdot \mathrm{L}^{-1}$ concentration.
Field management. Tomatoes were transplanted by hand into the high tunnel on 7 May 2015 and 29 Apr. 2016. 'Mountain Fresh Plus' tomatoes were grown with a stake and weave support system. 'Cherokee Purple' tomatoes were grown as a single leader using lower and lean trellis technique supported on Rollerhook (Johnny's Selected Seeds) attached support wire suspended $2 \mathrm{~m}$ above the soil. Irrigation was applied to provide $198,642 \mathrm{~L} /$ ha per week split into two applications. The entire high tunnel was mulched to a depth of $15 \mathrm{~cm}$ with switchgrass (Panicum virgatum). On 27 July 2015 and 9 June 2016, a 50\% shadecloth (Nolt's Midwest Produce Supplies, Charles City, IA) was placed over the top of the high tunnel to reduce irradiance and to moderate temperature.

Total and marketable fruit yields. Harvest took place 10 times from 22 July to 12 Oct. 2015 and 14 times from 6 July to 3 Oct. 2016. Fruit of 'Mountain Fresh Plus' were harvested at the breaker stage of ripeness and were graded following the USDA size standard (U.S. Department of Agriculture, 1991a; $\S 51.1859)$. Fruit categorized as "nonmarketable" included fruit $5.7 \mathrm{~cm}$ and smaller as well as fruit with major surface defects, insect feeding, and disease damage. 'Cherokee Purple' tomatoes were harvested at the pink to red stages according to the USDA maturity standards (U.S. Department of Agriculture, 1991b; §51.1860). Fruit were graded visually to determine marketability. Nonmarketable fruit of 'Cherokee Purple' were sorted into categories based on fruit cracking, sunscald, scab as a result of catfacing, severely misshapen fruit, and insect damage. Fruit count and weight were recorded for all categories of fruit.

Fruit quality and nutritional value. Postharvest fruit quality was determined by collecting multiple fruit samples of evenly ripened marketable fruit at the red stage [USDA maturity standards ( $(51.1860)$ ] for analysis during both years. Fruit were collected on 18 Sept. 2015 and 22 Aug. 2016 and held at room temperature $\left(21^{\circ} \mathrm{C}\right)$ for $4 \mathrm{~d}$. On day 5 , one whole fruit from each sample was selected for analysis of SSC. Each sample was blended in a food processor (Model \#FP1700B; Spectrum Brands Inc., Madison, WI), strained through six layers of cheesecloth into a clean weight boat, and $1 \mathrm{~mL}$ of the extract was transferred to a digital refractometer (Pocket Pal-1 refractometer; Atago, Tokyo, Japan). Three 1-mL subsamples from each fruit were analyzed.

Fruit samples for density and firmness were harvested on 18 Sept. 2015 and 5 Sept. 2016. Samples were held at $21{ }^{\circ} \mathrm{C}$ in a research laboratory for $4 \mathrm{~d}$. Five evenly ripened fruit samples per plot were used (selected from grade one marketable fruit) to measure density via a water-displacement method in which a container of water was filled to a predetermined water level (Ngouajio et al., 2003). Tubing attached to the container allowed water that was displaced by each tomato to be collected in a 
graduated cylinder. Displacement took place for each fruit individually to determine fruit volume that was compared with fruit weight to calculate density. After each displacement, sample water was added back into the container to restore the level. On 9 Sept. 2016, a penetrometer (Model 30B; Ballauf Devices, Derwood, MD) was used on marketable fruit to measure firmness. Two measurements were taken equatorially, $180^{\circ}$ apart on five uncut fruit per treatment. Data were not collected on firmness in 2015.

In 2016, several fruits in each treatment were tagged at breaker stage and harvested $7 \mathrm{~d}$ later on 9 Sept. for lycopene analysis (Taber et al., 2008). One grade-1 marketable fruit from each treatment was used for analysis. Using each whole tomato fruit, two equatorial cuts were made resulting in a slice $\approx 1.5 \mathrm{~cm}$ wide. Additional tomato flesh was removed until the sample weight of $100 \mathrm{~g}$ was reached. Weighed samples were individually bagged and stored at $-80{ }^{\circ} \mathrm{C}$ until extraction on 30 Sept. Samples were used for supernatant extraction as follows: Each sample was blended in a food processor (Model \#FP1700B; Spectrum Brands Inc.) with 300 $\mathrm{mL} 95 \%$ ethyl alcohol for $2 \mathrm{~min}$ and then transferred to a $500-\mathrm{mL}$ Nalgene bottle (Cole-Palmer, Vernon Hills, IL). The food processor was rinsed with an additional 50 $\mathrm{mL} 95 \%$ ethyl alcohol for a total of $350 \mathrm{~mL}$ 95\% ethyl alcohol. Samples (tomato plus ethyl alcohol) were centrifuged at 10,000 rpm for $10 \mathrm{~min}$ at $4{ }^{\circ} \mathrm{C}$ (Sorvall RC-5C Plus Superspeed Centrifuge; Kendro Laboratory Products, Ashville, NC). After centrifuging, the supernatant was collected and exact volume measured. The collected supernatant was used to determine lycopene content using the MTT assay analysis method as explained in Liu and Nair (2010).

Plant growth and vigor. During peak production (28 Aug. 2015 and 20 Aug. 2016), an indirect estimate of leaf chloro- phyll concentration was measured with a SPAD-502 Plus chlorophyll meter (Konica Minolta Sensing America Inc., Ramsey, NJ). Five readings were taken on the first fully developed leaf of a plant and averaged; this was repeated on five representative plants per plot. Research plots were ended on 20 Oct. 2015 and 7 Oct. 2016 when plant height and stem diameter were collected and whole plants were sampled destructively for biomass. Before biomass collection, five representative plants per plot were measured for stem diameter at a point $15 \mathrm{~cm}$ above the soil surface. End-of-season plant height was taken from the same five plants that were used to determine stem diameter. Height was measured from the soil to the terminal growing point. Due to frost damage on plants in 2015, plant height data are reported only for 2016. Three plants from each plot were collected to determine biomass by gathering all shoot tissue and digging a $45-\mathrm{cm}$ circumference hole to collect a uniform root sample. Roots and shoots from each plant were separated, and dried at $67^{\circ} \mathrm{C}$ in a forced-air oven until plants reached a constant weight.

Data analysis. Analysis of variance was conducted with the GLIMMIX procedure in SAS (version 9.4; SAS Institute, Cary, NC) to determine the fixed effects of year, cultivar, and grafting (and interactions) on yield, SSC, density, firmness, lycopene content, plant biomass, stem diameter, plant height, and estimated leaf chlorophyll content. Block and all interactions with block were random factors in all analyses. Means were separated according to Fisher's least significant difference test $(P \leq 0.05)$ using the "lsmeans" function.

\section{Results}

Total and marketable fruit yields. Mean total weight of marketable fruit was similar for grafted and nongrafted plants (Table 1), although 'Mountain Fresh Plus' outyielded 'Cherokee Purple' by $247 \%(P<0.0001)$. Yields from 'Mountain Fresh Plus' were reduced by an average of $38 \%$ in 2016 as compared with 2015. Mean total number of marketable fruit was increased by 16,200 per hectare by grafting when data were pooled across years $(P=0.040)$ (Table 1$)$. Mean total fruit from grafted plants was 24,675 more per hectare than from nongrafted plants $(P=$ $0.021)$. Grafting had no effect on individual fruit size (Table 1). 'Cherokee Purple' fruit were $18 \%$ heavier than fruit from 'Mountain Fresh Plus' $(P<0.0001)$ when averaged across year and graft treatment. Grafting with 'RST-04-106-T' did not influence percentage of marketable fruit by either weight or number in either year (Table 1).

Fruit quality and nutritional value. Mean $\mathrm{SSC}$ in fruit from grafted plants was 0.3 degrees lower than in fruit from nongrafted plants across years $(P=0.04)$ (Table 2). There were no differences in SSC within years except for an average increase of 0.9 degrees in fruit of 'Mountain Fresh Plus' from nongrafted plants vs. grafted plants in 2015. SSC in fruit from 'Cherokee Purple' were an average 0.3 degrees greater than in fruit from 'Mountain Fresh Plus' $(P=0.003)$. There was an interaction between grafting and year $(P=0.006)$. Fruit collected from nongrafted plants in 2015 had an average SSC of 5.4 degrees compared with 4.8 degrees in 2016 across cultivars. Fruit from grafted plants averaged 4.8 degrees in both years across cultivars (Table 2).

No differences were found in fruit density within or across years (Table 2). Firmness of fruit was unaffected by grafting (Table 2). Fruit from 'Mountain Fresh Plus' withstood an average of $0.6 \mathrm{~kg}$ more force than fruit from 'Cherokee Purple'. Grafting had no effect on fruit lycopene content as determined by absorbance at $570 \mathrm{~nm}$ (data not shown); however, there were differences

Table 1. Mean marketable fruit (weight and count), total fruit (weight and count), and marketability of grafted and nongrafted 'Cherokee Purple' and 'Mountain Fresh Plus' tomatoes grown 7 May to 20 Oct. 2015 and 29 April to 7 Oct. 2016 in a high tunnel at the Iowa State University Horticulture Research Station, Ames, IA. Data were collected from 10 plants in each treatment over a period of 10 harvests in 2015 and 14 harvests in 2016.

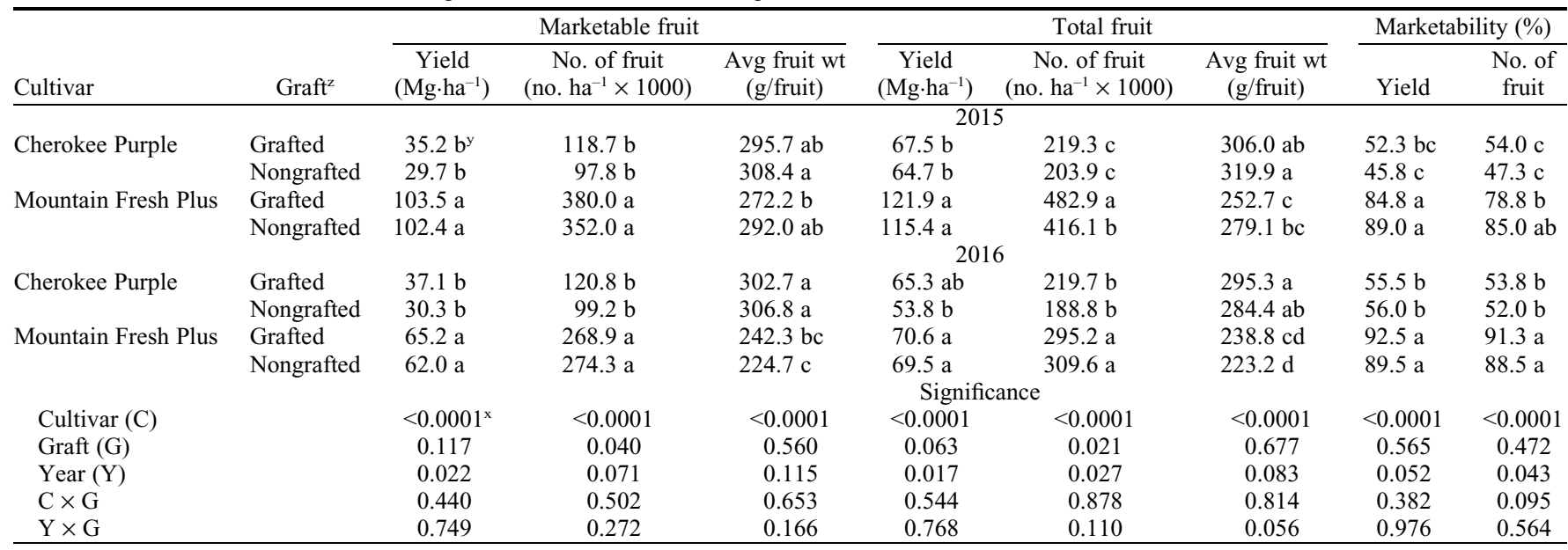

${ }^{\mathrm{z}}$ Rootstock 'RST-04-106-T' was used for grafted treatments.

${ }^{\mathrm{y}}$ Mean separation (within years in columns) based on Fisher's least significant differences at $P \leq 0.05$.

${ }^{\mathrm{x}} P$ values based on $\mathrm{F}$ test. 
Table 2. Soluble solids content (SSC), density, and firmness of grafted and nongrafted 'Cherokee Purple' and 'Mountain Fresh Plus' tomatoes grown in a high tunnel during 2015 and 2016 at the Iowa State University Horticulture Research Station in Ames, IA.

\begin{tabular}{|c|c|c|c|c|}
\hline Cultivar & $\mathrm{Graft}^{\mathrm{z}}$ & SSC $\left({ }^{\circ}\right.$ Brix $)$ & Density (kg/L) & Firmness $\left(\operatorname{kgf}^{y}\right)$ \\
\hline & & & 2015 & \\
\hline \multirow[t]{2}{*}{ Cherokee Purple } & Grafted & $5.1 \mathrm{ab}^{\mathrm{x}}$ & 1.022 & - \\
\hline & Nongrafted & $5.3 \mathrm{a}$ & 1.080 & - \\
\hline \multirow[t]{2}{*}{ Mountain Fresh Plus } & Grafted & $4.5 \mathrm{c}$ & 1.013 & - \\
\hline & Nongrafted & $5.4 \mathrm{a}$ & $\begin{array}{l}1.096 \\
2016\end{array}$ & - \\
\hline \multirow[t]{2}{*}{ Cherokee Purple } & Grafted & $5.0 \mathrm{~b}$ & 1.003 & $2.4 \mathrm{ab}$ \\
\hline & Nongrafted & $5.1 \mathrm{ab}$ & 0.957 & $1.8 \mathrm{~b}$ \\
\hline \multirow[t]{3}{*}{ Mountain Fresh Plus } & Grafted & $4.7 \mathrm{bc}$ & 1.072 & $2.8 \mathrm{a}$ \\
\hline & Nongrafted & $4.5 \mathrm{c}$ & 1.047 & $2.6 \mathrm{a}$ \\
\hline & & & Significance & \\
\hline Cultivar (C) & & $0.003^{w}$ & 0.204 & 0.017 \\
\hline Graft $(G)$ & & 0.036 & 0.580 & 0.088 \\
\hline Year (Y) & & 0.074 & 0.393 & - \\
\hline $\mathrm{C} \times \mathrm{G}$ & & 0.508 & 0.725 & 0.424 \\
\hline $\mathrm{Y} \times \mathrm{G}$ & & 0.006 & 0.112 & - \\
\hline
\end{tabular}

${ }^{\mathrm{z}}$ Rootstock 'RST-04-106-T' was used for grafted treatments.

${ }^{\mathrm{y}} \mathrm{kgf}=$ kilogram-force.

${ }^{\mathrm{x}}$ Mean separation (within years in columns) based on Fisher's least significant differences at $P \leq 0.05$.

${ }^{\mathrm{w}} P$ values based on $\mathrm{F}$ test.

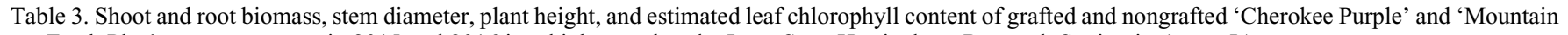
Fresh Plus' tomatoes grown in 2015 and 2016 in a high tunnel at the Iowa State Horticulture Research Station in Ames, IA.

\begin{tabular}{|c|c|c|c|c|c|c|}
\hline Cultivar & $\mathrm{Graft}^{\mathrm{z}}$ & $\begin{array}{c}\text { Shoot biomass } \\
(\mathrm{g} / \text { plant })\end{array}$ & $\begin{array}{c}\text { Root biomass } \\
(\mathrm{g} / \text { plant })\end{array}$ & $\begin{array}{l}\text { Stem diam } \\
(\mathrm{mm})\end{array}$ & $\begin{array}{l}\text { Plant ht } \\
(\mathrm{cm})\end{array}$ & $\begin{array}{c}\text { Chlorophyll content } \\
\text { (SPAD) }\end{array}$ \\
\hline & & & & 2015 & & \\
\hline \multirow{2}{*}{ Cherokee Purple } & Grafted & $111.7 b^{y}$ & $5.8 \mathrm{c}$ & $15.4 \mathrm{a}$ & - & $44.4 \mathrm{bc}$ \\
\hline & Nongrafted & $115.6 \mathrm{~b}$ & $5.8 \mathrm{c}$ & $14.7 \mathrm{ab}$ & - & $43.4 \mathrm{bc}$ \\
\hline \multirow[t]{2}{*}{ Mountain Fresh Plus } & Grafted & $339.8 \mathrm{a}$ & $14.9 \mathrm{a}$ & $15.2 \mathrm{ab}$ & - & $45.7 \mathrm{ab}$ \\
\hline & Nongrafted & $346.2 \mathrm{a}$ & $12.9 \mathrm{ab}$ & $\begin{array}{r}14.3 \mathrm{~b} \\
2016\end{array}$ & - & $47.0 \mathrm{a}$ \\
\hline \multirow[t]{2}{*}{ Cherokee Purple } & Grafted & $154.6 \mathrm{~b}$ & $8.0 \mathrm{~b}$ & 15.1 & $278.0 \mathrm{a}$ & $44.0 \mathrm{~cd}$ \\
\hline & Nongrafted & $145.2 \mathrm{~b}$ & $7.5 \mathrm{~b}$ & 14.4 & $259.2 \mathrm{a}$ & $42.8 \mathrm{~d}$ \\
\hline \multirow[t]{3}{*}{ Mountain Fresh Plus } & Grafted & $338.8 \mathrm{a}$ & $11.6 \mathrm{a}$ & 15.2 & $143.0 \mathrm{~b}$ & $47.9 \mathrm{ab}$ \\
\hline & Nongrafted & $334.0 \mathrm{a}$ & $10.9 \mathrm{a}$ & 14.3 & $145.6 \mathrm{~b}$ & $49.5 \mathrm{a}$ \\
\hline & & & & Significance & & \\
\hline Cultivar (C) & & $<0.0001^{\mathrm{x}}$ & $<0.0001$ & 0.556 & $<0.0001$ & $<0.0001$ \\
\hline Graft (G) & & 0.975 & 0.162 & 0.005 & 0.551 & 0.725 \\
\hline Year (Y) & & 0.467 & 0.570 & 0.689 & - & 0.168 \\
\hline $\mathrm{C} \times \mathrm{G}$ & & 0.838 & 0.340 & 0.708 & 0.437 & 0.047 \\
\hline $\mathrm{Y} \times \mathrm{G}$ & & 0.773 & 0.719 & 0.978 & - & 0.958 \\
\hline
\end{tabular}



${ }^{\mathrm{y}}$ Mean separation (within years in columns) based on Fisher's least significant differences at $P \leq 0.05$.

${ }^{\mathrm{x}} P$ values based on $\mathrm{F}$ test.

between cultivars. Mean absorbance for fruit samples was higher for 'Cherokee Purple' by 0.0171 points as compared with 'Mountain Fresh Plus' $(P=0.004)$.

Plant growth and vigor. 'RST-04-106-T' rootstock did not increase shoot biomass (Table 3). Root biomass was similar for 'Cherokee Purple', 'Mountain Fresh Plus', and the hybrid rootstock. Both shoot and root biomass were greater for 'Mountain Fresh Plus' than for 'Cherokee Purple' $(P<0.0001)$. The average diameter of the scion stem was $0.8 \mathrm{~mm}$ greater for plants grafted to 'RST-04-106-T' than for nongrafted plants $(P=0.005)$ (Table 3$)$. Stem width of 'Cherokee Purple' and 'Mountain Fresh Plus' did not differ. Plant height was equal between grafted and nongrafted plants in 2016 (Table 3). Grafted and nongrafted plants had similar estimated leaf chlorophyll content; however, there was a mild interaction between cultivar and grafting $(P=0.05)$ (Table 3). Grafted plants of 'Cherokee Purple' had a mean SPAD reading
1.1 points higher than that of nongrafted plants, but grafted plants of 'Mountain Fresh Plus' mean SPAD reading was 1.5 points lower than that of nongrafted plants.

\section{Discussion}

As the use of grafted tomatoes increases in the United States, it is valuable to explore this production technique for Midwest growers. Our results suggest that the rootstock used in the study, 'RST-04-106-T', provided only marginal yield benefits with reduction in fruit total SSC, and no improvement in plant vigor. The lack of a more significant response in yield may have been due to the absence of soil-borne pathogens within the high tunnel site during both growing seasons. With growing conditions that were not severely impacted by disease, salinity, or nutrient deficiency the rootstock, 'RST-04-106-T', did not outperform nongrafted plants.
Research examining the rootstock 'RST04-106-T' has been somewhat limited, and has largely focused on performance in conditions where disease is present (Kunwar et al., 2015; McAvoy et al., 2012). McAvoy et al. (2012) found that plants grafted to 'RST-04-106-T' did have a lower disease incidence and higher yields in fields naturally infested with Ralstonia solanacearum when compared with nongrafted and self-grafted controls, but this trend was found in only 1 of the 2 years examined. Kunwar et al. (2015) found that the use of 'RST-04-106-T' reduced the incidence of root gall in conditions where root-knot nematodes (Meloidogyne incognita) were present, but this did not significantly increase yield over nongrafted controls. These two studies point out that, even in the presence of soil-borne disease, 'RST-04-106-T' may not be the best choice.

Work conducted by Meyer (2016) in Midwest field trials found that 'RST-04106-T' performance did not exceed that of nongrafted plants across three field sites 
during 2013 and 2014. In one case, marketable yield (weight) was actually less than that from nongrafted plants. The work of Meyer (2016) also found no increase in fruit size because of grafting with 'RST-04-106-T', which aligns with our findings.

Our results showed that the use of 'RST04-106-T' did not significantly increase plant vigor with the exception of an increase in stem diameter. This aligns with Meyer (2016), who found no increase in plant biomass with shoots collected from plants grafted to 'RST-04-106-T'. Alternative rootstocks have been shown to increase plant vigor in environments in which soil pathogens are present. For example, Buller et al. (2013) found that stem diameter of 'Cherokee Purple' was larger for plants grafted to the rootstock 'Maxifort' in a soil infested with verticillium wilt, although the disease itself did not affect the plants. Plant height of 'Cherokee Purple' was larger for plants grafted to the rootstock 'Beaufort'. Barrett et al., (2012a) found an increase in plant biomass for two different heirloom tomato cultivars grafted to 'Multifort' rootstock grown in soil infested with root-knot nematode, but this only occurred in 1 of 2 years in each case.

Our work found a decrease in SSC in fruit from grafted plants, which contradicts the work of Buller et al. (2013), who found no effect of grafting on SSC in 'Cherokee Purple'. The key difference here being the rootstock types, 'RST-04-106-T' in our study and 'Beaufort' and 'Maxifort' used by Buller et al. (2013). Their study found no increase in fruit firmness or lycopene content due to the use of grafting, which is consistent with our findings.

From an economic standpoint, grafting with the rootstock 'RST-04-106-T' might not be justifiable. Rysin and Louws (2015) found in their economic analysis comparing grafted and nongrafted systems that a $35 \%$ increase in marketable fruit weight would be needed to reach a break-even point. Our work found a $20.5 \%$ increase in weight of 'Cherokee Purple' and only a $2.6 \%$ increase in marketable weight of 'Mountain Fresh Plus'. These data do show a potential discrepancy between the effects of grafting on heirloom vs. hybrid tomatoes. Overall, our work is limited in scope to a critique of 'RST-04-106-T' and alternative rootstocks should be used within our system to draw further conclusions. In addition, cost associated with using grafted plants could vary depending if the grafted plant was purchased externally or grafting was performed in-house.

\section{Conclusions}

Although proven to succeed in soils infested with bacterial wilt, 'RST-04-106-T' does not appear to be a viable rootstock to use when growing grafted tomatoes in the absence of soil-borne disease pressure. The marginal increase in yield would not be enough to offset the increased cost of using grafted plants. In addition, when considering the detrimental effects on fruit quality and the lack of increased plant vigor across multiple parameters, there is no additional evidence to support the use of this rootstock in a field without a history of production challenges. However, research conducted at several land grant universities in the United States have advanced the science and application of grafting in vegetable crop production. Growers now have access to advanced high-performing rootstocks that address a wide array of production challenges. Based on our findings, alternative rootstocks should be used in Midwest high tunnels, and additional, localized trials that meet the needs of regional production challenges should continue. To move the grafting industry forward, future research should expand scion-rootstock combinations in relation to water, soil fertility, and extreme weather conditions.

\section{Literature Cited}

Asins, M.J., V. Raga, D. Roca, A. Belver, and E.A. Carbonell. 2015. Genetic dissection of tomato rootstock effects on scion traits under moderate salinity. Theor. Appl. Genet. 128:667-679.

Barrett, C.E., X. Zhao, and A.W. Hodges. 2012a. Cost benefit analysis of using grafted transplants for root-knot nematode management in organic heirloom tomato production. HortTechnology 22:252-257.

Barrett, C.E., X. Zhao, C.A. Sims, J.K. Brecht, E.Q. Dreyer, and Z. Gao. 2012b. Fruit composition and sensory attributes of organic heirloom tomatoes as affected by grafting. HortTechnology 22:804-809.

Bhatt, R.M., K.K. Upreti, M.H. Divya, S. Bhat, C.B. Pavithra, and A.T. Sadashiva. 2015. Interspecific grafting to enhance physiological resilience to flooding stress in tomato (Solanum lycopersicum L.). Scientia Hort. 182:8-17.

Borgognone, D., G. Colla, Y. Rouphael, M. Cardarelli, E. Rea, and D. Schwarz. 2013. Effect of nitrogen form and nutrient solution $\mathrm{pH}$ on growth and mineral composition of selfgrafted and grafted tomatoes. Scientia Hort. 149:61-69.

Buller, S., D. Inglis, and C. Miles. 2013. Plant growth, fruit yield and quality, and tolerance to Verticillium wilt of grafted watermelon and tomato in field production in the Pacific Northwest. HortScience 48:1003-1009.

Brennan, E.B. 2013. Agronomic aspects of strip intercropping lettuce with alyssum for biological control of aphids. Biol. Control 65:302311.

Bruce, A., J. Farmer, E. Maynard, and J. Valliant. 2017. Assessing the impact of the EQIP High Tunnel Initiative. J. of Ag., Food Systems, and Community Dev. 7(3):1-22.

Carey, E.E., L. Jett, W.J. Lamont, T.T. Nennich, M.D. Orzolek, and K.A. Williams. 2009. Horticultural crop production in high tunnels in the United States: A snapshot. HortTechnology 19:37-43.

Djidonou, D., K. Lopiano, X. Zhao, E.H. Simonne, J.E. Erickson, and K.E. Koch. 2015. Estimating nitrogen nutritional crop requirements of grafted tomatoes under field conditions. Scientia Hort. 182:18-26.

Djidonou, D., X. Zhao, E.H. Simonne, K.E. Koch, and J.E. Erickson. 2013. Yield, water-, and nitrogen-use efficiency in field-grown, grafted tomatoes. HortScience 48:485-492.
Enderton, A., C. Bregendahl, D. Swenson, and L. Adcock. 2017. Iowa commercial horticulture food crop survey results. Iowa Dept. of Ag. and Land Stewardship, Des Moines, IA. Iowa State Univ. Extension and Outreach, Ames, IA.

Fan, M., Z. Bie, A. Krumbein, and D. Schwarz. 2011. Salinity stress in tomatoes can be alleviated by grafting and potassium depending on the rootstock and K-concentration employed. Scientia Hort. 130:615-623.

Flores, F.B., P. Sanchez-Bel, M.T. Estañ, M.M. Martinez-Rodriguez, E. Moyano, B. Morales, J.F. Campos, J.O. Garcia-Abellán, M.I. Egea, N. Fernández-Garcia, F. Romojaro, and M.C. Bolarín. 2010. The effectiveness of grafting to improve tomato fruit quality. Scientia Hort. 125:211-217.

Guan, W., X. Zhao, R. Hassell, and J. Thies. 2012. Defense mechanisms involved in disease resistance of grafted vegetables. HortScience 47:164-170.

Jett, L.W. 2017. 6 - High tunnels, p. 107-116. In: M.D. Orzolek (ed.). A guide to the manufacture, performance, and potential of plastics in agriculture. Elsevier, Atlanta, GA.

King, S.R., A.R. Davis, X. Zhang, and K. Crosby. 2010. Genetics, breeding and selection of rootstocks for Solanaceae and Cucurbitaceae. Scientia Hort. 127:106-111.

Knewtson, S.J.B., R. Janke, M.B. Kirkham, K.A. Williams, and E.E. Carey. 2010. Trends in soil quality under high tunnels. HortScience 45:1534-1538.

Kubota, C., M.A. McClure, N. Kokalis-Burelle, M.G. Bausher, and E.N. Rosskopf. 2008. Vegetable grafting: History, use, and current technology status in North America. HortScience 43:1664-1669.

Kunwar, S., M.L. Paret, S.M. Olson, L. Ritchie, J.R. Rich, J. Freeman, and T. McAvoy. 2015. Grafting using rootstocks with resistance to Ralstonia solanacearum against Meloidogyne incognita in tomato production. Plant Dis. 99:119-124.

Lamont, W.J. 2009. Overview of the use of high tunnels worldwide. HortTechnology 19:25-29.

Lamont, W.J., M.D. Orzolek, E.J. Holcomb, K. Demchak, E. Burkhart, L. White, and B. Dye. 2003. Production system for horticultural crops grown in the Penn State high tunnel. HortTechnology 13:358-362.

Lee, J.M., C. Kubota, S.J. Tsao, Z. Bie, P.H. Echevarria, L. Morra, and M. Oda. 2010. Current status of vegetable grafting: Diffusion, grafting techniques, automation. Scientia Hort. 127:93-105.

Leonardi, C. and F. Giuffrida. 2006. Variation of plant growth and macronutrient uptake in grafted tomatoes and eggplants on three different rootstocks. Eur. J. Hort. Sci. 71:97-101.

Lewis, M., C. Kubota, R. Tronstad, and Y.J. Son 2014. Scenario-based cost analysis for vegetable grafting nurseries of different technologies and sizes. HortScience 49:917-930.

Liu, N., B. Zhou, X. Zhao, B. Lu, Y. Li, and J. Hao. 2009. Grafting eggplant onto tomato rootstock to suppress Verticillium dahliae infection: The effect of root exudates. HortScience 44:20582062.

Liu, Y. and M.G. Nair. 2010. An efficient and economical MTT assay for determining the antioxidant activity of plant natural product extracts and pure compounds. J. Nat. Prod. 73:1193-1195.

Louws, F.J., C.L. Rivard, and C. Kubota. 2010. Grafting fruiting vegetables to manage soilborne pathogens, foliar pathogens, arthropods and weeds. Scientia Hort. 127:127-146. 
McAvoy, T., J.H. Freeman, S.L. Rideout, S.M. Olson, and M.L. Paret. 2012. Evaluation of grafting using hybrid rootstocks for management of bacterial wilt in field tomato production. HortScience 47:621-625.

Meyer, L. 2016. Grafting to increase high tunnel tomato productivity in the central United States. Kansas State Univ., Manhattan, MS Thesis.

Ngouajio, M., W. Kirk, and R. Goldy. 2003. A simple model for rapid and nondestructive estimation of bell pepper fruit volume. HortScience 38:509-511.

Nicoletto, C., F. Tosini, and P. Sambo. 2013. Effect of grafting on biochemical and nutritional traits of "Cuore di Bue" tomatoes harvested at different ripening stages. Acta Agr. Scand. Sect. B 63:114-122.

Nilsen, E.T., J. Freeman, R. Grene, and J. Tokuhisa. 2014. A rootstock provides water conservation for a grafted commercial tomato (Solanum lycopersicum L.) line in response to mild-drought conditions: A focus on vegetative growth and photosynthetic parameters. PLoS One 9:1-22.

Ntatsi, G., D. Savvas, G. Ntatsi, H.-P. Kläring, and D. Schwarz. 2014. Growth, yield, and metabolic responses of temperature-stressed tomato to grafting onto rootstocks differing in cold tolerance. J. Amer. Soc. Hort. Sci. 139:230 243.

O’Connell, S., C. Rivard, M.M. Peet, C. Harlow, and F. Louws. 2012. High tunnel and field production of organic heirloom tomatoes: Yield, fruit quality, disease, and microclimate. HortScience 47:1283-1290.

Reeve, J. and D. Drost. 2012. Yields and soil quality under transitional organic high tunnel tomatoes. HortScience 47:38-44.

Rouphael, Y., D. Schwarz, A. Krumbein, and G. Colla. 2010. Impact of grafting on product quality of fruit vegetables. Scientia Hort. 127:172-179.

Rysin, O. and F.J. Louws. 2015. Decision tool for growers to evaluate economic impact of grafting technology adoption: An application to open-field conventional tomato production. HortTechnology 25:132-138.

Rysin, O., C. Rivard, and F.J. Louws. 2015. Is vegetable grafting economically viable in the United States: Evidence from four different tomato production systems. Acta Hort. 1086: 79-86.

Sánchez-Rodríguez, E., M.M. Rubio-Wilhelmi, B. Blasco, R. Leyva, L. Romero, and J.M. Ruiz. 2012. Antioxidant response resides in the shoot in reciprocal grafts of drought-tolerant and drought-sensitive cultivars in tomato under water stress. Plant Sci. 188-189:89-96.

Schwarz, D., G.B. Öztekin, Y. Tüzel, B. Brückner, and A. Krumbein. 2013. Rootstocks can enhance tomato growth and quality characteristics at low potassium supply. Scientia Hort. 149:70-79.

Schwarz, D., Y. Rouphael, G. Colla, and J.H. Venema. 2010. Grafting as a tool to improve tolerance of vegetables to abiotic stresses: Thermal stress, water stress and organic pollutants. Scientia Hort. 127:162-171.

Taber, H., P. Perkins-Veazie, S. Li, W. White, S. Rodermel, and Y. Xu. 2008. Enhancement of tomato fruit lycopene by potassium is cultivar dependent. HortScience 43:159-165.

USDA, National Agricultural Statistics Service. 2014. 2012 Census of agriculture. Iowa state and county data. Volume 1: Part 15. U.S. Dept. of Agr., Washington, DC.

U.S. Department of Agriculture. 1991a. United States standards for grades of fresh tomatoes: Size $\$ 51.1859$. U.S. Dept. of Agr., Washington, DC. 3 Jan. 2019. <https://www.ams.usda.gov/ sites/default/files/media/Tomato_Standard\% $5 \mathrm{~B} 1 \% 5 \mathrm{D} . \mathrm{pdf}>$.

U.S. Department of Agriculture. 1991b. United States standards for grades of fresh tomatoes: Color classification $\$ 51.1860$. U.S. Dept. of Agr., Washington, DC. 3 Jan. 2019. <https:// www.ams.usda.gov/sites/default/files/media/ Tomato_Standard\%5B1\%5D.pdf>.

Vitale, A., M. Rocco, S. Arena, F. Giuffrida, C. Cassaniti, A. Scaloni, T. Lomaglio, V. Guarnaccia, G. Polizzi, M. Marra, and C. Leonardi. 2014. Tomato susceptibility to Fusarium crown and root rot: Effect of grafting combination and proteomic analysis of tolerance expression in the rootstock. Plant Physiol. Biochem. 83:207-216.

Waterer, D. 2003. Yields and economics of high tunnels for production of warm-season vegetable crops. HortTechnology 13:339-343. 